Animal behaviour

\section{J.P. Hailman}

The Ecology and Evolution of Animal Behavior. Second edition. By Robert A. Wallace. Pp.284. (Goodyear: Santa Monica, California, 1979.) Price please. Animal Behavior: An Evolutionary Approach. Second edition. By John Alcock. Pp.532. (Sinauer Associates: Sunderland, Massachusetts, 1979.) $\$ 16.00$ cloth. Evolution of Behaviour. By Jerram L. Brown. Pp.760. (W.W. Norton: New York, 1975.) \$17.95. Insect Behaviour. By Robert W. Matthews and Janice R. Matthews. Pp.507. (John Wiley: New York and Chichester, UK, 1978.) \$32.40. Comparative Animal Behaviour. By Donald A. Dewsbury. Pp.452. (McGrawHill: New York and London, 1978.) $\$ 17.95$.

THE closing year of the decade added at least three textbooks on the increasingly popular study of animal behaviour. Robert A. Wallace's Ecology and Evolution of Animal Behavior appears in a second edition, with 16 chapters embracing such topics as "classical instinct theory", drive, learning, communication, sex, aggression and social behaviour including altruism and warfare. The frontispiece is clearly a discus (Symphysodon), and on page 118 where the figure is repeated we learn that it illustrates "false eyespots near their tail."

The figure might be symptomatic of a second major problem of this book: the common discus species known to aquarium buffs ( $S$. aequifasciata and $S$. discus) have no such eyespots, I cannot find such a marking in illustrations of Symphysodon species, and an ichthyologically knowledgeable colleague knows of no such species. It would have been useful for the book to identify all species illustrated. Surely the "peregrine falcon" in figure 2.2 is peculiar for the species, and in any case is landing rather than hunting as asserted. Sea horses (figure 2.5) suck up prey somewhat like a vacuum cleaner does, rather than snapping them as asserted. Although some instructors may like the chatty, anecdotal nature of the text, I find it slightly condescending and certainly no paragon for undergraduate writing.

John Alcock's widely used Animal Behavior: An Evolutionary Approach appears in a second edition that shows some, but not marked, improvement over the first. This is not a general text on behaviour, but rather is aimed at ecological and evolutionary aspects. There is some material on immediate control of behaviour and its physiological mechanisms, but the author deals only briefly with learning and ontogenetic development. Indeed, the brief treatment of ontogeny is totally puzzling, as evidenced by such sentences as: "Please note that I am NOT arguing that innate behavior patterns are genetic or more genetic than learned behaviors." When Alcock is in his evolutionary element, however, the text is extremely good, and I believe that a perceptive instructor could utilise it in conjunction with other material.

Because of the similarity with Alcock's book, Jerram L. Brown's Evolution of Behavior deserves at least passing mention. The focus is the same, but there is more material on both physiological mechanisms and ontogenetic development of behaviour, making the book more comprehensive, if a few years older. Like Alcock and most other evolutionary behaviourists, Brown finds environmental influences on the development of behaviour slightly annoying, but at least he faces the annoyance reasonably honestly rather than trying to explain it away with semantics.

For entomological ethologists the new Insect Behavior by Robert W. and Janice R. Matthews is the first real text of its kind. Although I claim no expertise in insect behaviour, 1 found the organisation of this book well suited to its subject matter, and those subjects that I know something about to be treated well. Finally, one need mention Donald A. Dewsbury's Comparative Animal Behavior, a book (by a psychologist) with too much elementary zoological material but with a marvellous balance of treatment among the four classes of behavioural determinants control, ontogeny, perpetuation and phylogeny of behaviour. The text is not, however, orientated substantially toward natural history and field studies, so has not earned plaudits from my students to match my own.

It is difficult to escape the conclusion that a really outstanding text on animal behaviour has yet to be written for a modern audience. Many teachers still rely on one of the three originals, two in revised editions: Mechanisms of Animal Behavior by Peter Marler and William J. Hamilton III (Wiley: New York and Chichester, UK, 1966), An Introduction to Animal Behavior: Ethology's First Century by Peter H. Klopfer (Prentice-Hall: Englewood Cliffs, New Jersey, 1974) or Animal Behaviour: A Synthesis of Ethology and Comparaive Psychology by Robert A. Hinde (McGraw-Hill: New York, 1970). Each has its own strengths and weaknesses and all have been well reviewed over the years. A cynic might prefer to follow the dictum of Louis Agassiz: "Learn from nature, not books.",

J.P. Hailman is Professor of Zoology at the University of Wisconsin, Madison, Wisconsin.

\section{Introductory chemistry for the health sciences}

\section{A.D. Cooper}

Chemical Principles for Life. By Lois Forney. Pp.574. (Prentice-Hall: Englewood Cliffs, New Jersey, 1978.) \$14.95. Elements of General and Biological Chemistry. Fifth edition. By John Holum. Pp.571. (Wiley: New York, 1979.) \$16.95. Chemical Principles for the Life Sciences. Second edition. By Ralph Fessenden and Joan Fessenden. Pp.526. (Allyn and Bacon: Boston, 1979.) \$18.95.

ALL three texts are well written. Forney writes at a higher lever than the other authors. Particularly difficult concepts covered by Forney are: thermodynamics, Henderson-Hasselbach equation, coupled reactions, standard reduction potentials and titration curves. Difficult concepts are often covered relatively early in the text.
Holum writes at a lower level than the others. Fessenden and Fessenden write at an intermediate level that can be understood by most students. The authors are patient and approach each topic in a systematic way. Difficult concepts covered by the Fessendens are equilibrium constants and coupled reactions. In general, Forney and the Fessendens define terms more clearly than does Holum.

Of the three texts, Holum's has the most special features. Each chapter has a summary, selected readings and ample questions. Worked out examples are included and answers to in-chapter exercises are at the back of the book. Appendices include mathematical manipulations, inorganic and organic nomenclature, and data on nutrition. At the end of each chapter the Forney text has a programmed review that includes fill-inthe-blank questions with answers in the left-hand margin. Some of the chapters have additional questions and mathematical problems. Worked out examples are included. No appendices are given. The Fessenden text has a set of objectives at the start of each chapter and study questions at the end. Numerous well 